\author{
VOLODYMYR SKVORETS, \\ Zaporizhzhia National University (Zaporizhzhya, Ukraine) \\ e-mail: skvorets.v.o@gmail.com, ORCID0000-0001-7558-0773
}

IGOR KUDINOV,

Zaporizhzhia National University (Zaporizhzhya, Ukraine)

e-mail: info@igorkudinov.pro,ORCID 0000-0001-7785-1637

\title{
SOCIO-CULTURAL TRANSFORMATION IN POST-SOVIET UKRAINE
}

\begin{abstract}
The relevance of the research problem is that the understanding of socio-cultural transformation allows us to identify social processes that affect the functioning of post-Soviet Ukrainian society. The research subject is the social processes that determine the content and nature of socio-cultural transformation of post-Soviet Ukrainian society. The purpose of the article is to comprehend the impact of socio-cultural changes on the functioning of post-Soviet Ukrainian society. The methodology of the socio-cultural transformation research is based on the use of systematic, logical, historical, dialectical and socio-cultural approaches and methods. The results of scientific research. In post-Soviet Ukraine, the general context of socio-cultural change is due to the implementation of market reforms that have led to privatization, deindustrialization, mass marginalization, transition to a liberal state and depopulation. These processes have led to socio-cultural changes in the lives of Ukrainian citizens. There were important changes in the social sphere, the social structure of the population, the distribution of national wealth, which changed the direction of its movement from the dominance of social development to the predominance of social degradation. There was a change in the social matrix of society's reproduction: there was a transition from the dominance of the middle classes' culture to the spread of the culture of the poor, the main feature of which is the struggle for survival. The essence of the socio-cultural transformation of post-Soviet Ukrainian society is the transition from the absolutism of the state to the absolutism of the market, which means the transformation of everything possible into a commodity, and the dominance of commodity-money relations in all spheres of public life. This transition was accompanied by a change in the historical and cultural type of human personality, commercialization, deprofessionalization, as well as the primitivization of public administration. Changes in the culture's state have complicated the reproduction of society as a whole. The Soviet way of life has been dismantled, and the failure of the social matrix indicates that a new way of life in post-Soviet Ukraine has not yet been formed, and therefore socio-cultural transformation must be aimed at its formation. The practical value of the results lies in substantiating the content of socio-cultural transformation in post-Soviet Ukraine and its impact on the functioning of society.
\end{abstract}

Key word: People Living Arrangement, social matrix, social reproduction, social transformation, social development, social degradation, socio-cultural changes.

\section{Introduction}

In the year of the thirtieth anniversary of Ukraine's independence, the problem of socio-cultural changes in our society deserves special attention. The path of establishing an independent Ukraine was accompanied not only by contradictory social processes, but also by social changes unexpected for its citizens. On this path were both gains (establishment of democratic institutions; declaring the priority of human rights; transition from a planned economy dominated by state ownership to a market economy based mainly on private property) and losses (formation of lines of social breakdown, threatening the loss of society and the state integrity, the emergence in some regions of the mood of citizens, which enabled Russia's annexation of Crimea and the military conflict in eastern Ukraine).

ISSN 1728-9343 (Print)

ISSN 2411-3093 (Online)
In modern Ukraine, there are very few studies that, from the standpoint of philosophical reflection, consider the social changes that characterize the transformation of post-Soviet Ukrainian society. An attempt to substantiate the general picture of social change in Ukraine is found in two monographs by sociologist M. Shulga: "Drift to the sidelines. Twenty years of social change in Ukraine" (2011) and "Failure of the social matrix" (2018). The titles of these monographs indicate the nature of social changes that led to the drift of Ukrainian society to the margins of civilization, and then to the failure of the social matrix that ensures the preservation of society. In 2001, M. Pavlovsky's book "Strategy for the development of society: Ukraine and the world (economics, political science, sociology)" was published, which has not lost its relevance because it warned against threats leading to

SKHID Vol. 1 (2) May-June 2021 
the degradation of society. In 2019 Volodymyr Skvorets published a monograph "Transformation of the sociohistorical organism of Ukraine: analysis of social processes" (Skvorets, 2019), which attempts to analyze the processes that determine the nature of social change in postSoviet Ukrainian society.

The urgent needs of social governance and practical policy require a deep understanding of where modern Ukrainian society is heading, what social changes are fundamental for it, what transforms it, what basic processes shape the future of Ukrainian society as a social system. In this context, socio-cultural changes in postSoviet Ukraine remain poorly studied.

The research purpose is to understand the impact of socio-cultural changes on the functioning of post-Soviet Ukrainian society. This purpose is realized in the following tasks:

- substantiation of the general context of the main factors influence on socio-cultural changes in the post-Soviet Ukrainian society;

- analysis of the relationship between social development and socio-cultural changes in post-Soviet Ukrainian society;

- analysis of changes in the model of social management as a natural result of socio-cultural transformation of Ukraine.

\section{Methods}

Systematic, logical, historical, dialectical and sociocultural approaches and methods were used to study socio-cultural transformation in post-Soviet Ukraine. A systematic analysis of the changes caused by market reforms has identified the main social processes that characterize the transformation of Ukrainian society as a whole. Logical analysis using the concepts of "People Living Arrangement" and "social matrix" provided a study of the impact of social processes on social reproduction as a basis for preserving the social organism of the country. The historical method provided an analysis of the state of certain processes as a result of social and sociocultural changes. The dialectical method was used to analyze the process of social change during the movement from the Soviet model to the post-Soviet one. The socio-cultural method was used to comprehend the influence of economic, social and political factors on culture, as well as culture on various spheres of life of Ukrainian society.

\section{Result and Discussions}

Concepts of People Living Arrangement and social matrix as a theoretical basis for the analysis of social changes in post-Soviet Ukraine. At the heart of the movement of Ukrainian society from the Soviet to the post-Soviet state was the imbalance between social reproduction and transformation. A. Giddens recognized the study of the relationship between social reproduction and transformation as a sociological problem. "Continuity and variability in public life can be represented as a "mixture" of intentional and unintentional consequences of human actions. The task of sociology is to investigate the result- ing balance between social reproduction and transformation. Social reproduction shows how society "maintains its life" over time, transformation means the changes to which societies are subject. ... Social reproduction is a consequence of the continuity of actions performed by people from day to day and from year to year, as well as the continuity of various social practices followed by people" (Giddens, 1999: 32-34).

Volodymyr Skvorets had to analyze the problem of social (public) reproduction in the dissertation research "People living arrangement: socio-philosophical analysis". The People Living Arrangement is a concept denoting the historically formed order of interrelation of the person, the nature and a society providing integration of subjects of vital activity in a certain social organism of the country and reproduction of the last as organic integrity which is based on processes including reproduction of the person, economic system, social structure, political system, technosphere, socio-cultural sphere and way of life of social actors (Skvorets, 2013: 10). The content of this concept includes seven system elements, the reproduction of which together ensures the reproduction and preservation of the integrity of any society. Identifying trends in the reproduction of each of these elements, as well as identifying the interdependencies between them provides a basis for identifying the direction and nature of social transformation.

In search of the basis of social reproduction, the sociologist M. Shulga introduced the concept of social matrix, which meant the paradigm of society. The social matrix is seen as the basic structure of social relations that provide this type of society's existence or its way of life. It embodies the principles of the social order of this society. The matrix is a hidden paradigm of the principles of activity and thinking, a form of reactions based on collective myths and traditions. It is the result of long-term evolution of a particular social organism, formed under the influence of many factors of the natural and social environment. The matrix is the deep foundation of a stable system of social practices that ensure the reproduction of the latter in the natural and social environment. The social matrix includes a model of attitude to the world, methods and forms of its development, which has historically developed in this society. On the basis of established social practices, a picture of the world, an idea of the main features of the world order and an understanding of the meaning of relations between its social structures are formed. These ideas and understandings form the core of the culture of a given society, which is maintained and reproduced throughout the historical epoch. The most profound and vital relationships, i.e. those that form the basis of society, which ultimately determine the integrity, stability over time and quality reproduction of society, can be defined as a social matrix in a broad sense (Shulha, 2018: 14-15).

The concepts of "People Living Arrangement" and "social matrix" were introduced to denote certain mechanisms of social reproduction that ensure the preservation of society's integrity. The content of both of these concepts is based on the understanding of society as a social 
organism, which emphasizes such a property of social reproduction as the ability to ensure and preserve its integrity. The concept of "People Living Arrangement" reflects the desire to combine systemic elements of the formational approach (economic, social, political system and spiritual sphere) and civilizational approach (reproduction of man, technosphere, socio-cultural sphere and way of life of social actors). The concept of "social matrix" focuses on socio-cultural factors of social reproduction of the social system.

Thus, based on the concept of People Living Arrangement and social matrix, we obtain methodological tools that allow us to determine the impact of factors that strengthen or weaken the integrity of society.

What processes had an impact on the cultural transformation of Ukraine?

Already in the process of Ukraine's independence, the country's ruling circles announced a course for market reforms and democratization of the country's life, but the path they took in the movement of Ukrainian society led to results that were far from the expectations and hopes of most Ukrainians. This was especially evident in the first decade of reforms. Nobel laureate Joseph Stiglitz wrote: "For most people in the former Soviet Union, economic life under capitalism turned out to be even worse than the old communist leaders said. The prospects for the future are bleak. The middle class has been destroyed, a system of "godfather's" and mafia capitalism has been created, and the only achievement - the introduction of democracy with important freedoms, including freedom of the press - is at best not strong enough" (Stiglitz, 2002: 125-136).

According to M. Pavlovsky, a special type of reforms were the reforms carried out in post-socialist countries. They are associated with the transition from a centrally planned to a market economy. These economic reforms transform society, lead to a change in the socio-economic environment. Reform as a transition from socialism to market relations in the second half of the twentieth century was conducted on two models. The first is based on the only model of the Chicago neoconservative school based on Friedman's monetarism theory, which was implemented by the International Monetary Fund and the World Bank in both Latin American and post-socialist countries. The second is the model of reforms of the People's Republic of China, which is based on the innovative theory of $\mathrm{M}$. Tugan-Baranovsky, based on innovation and investment in priority areas. Reforms under the first model proved to be extremely costly and destructive. Over the years of reform, Ukraine has lost almost $75 \%$ of its economic potential and has been pushed out of the top ten most developed countries in the world. During the years of reforms, China had a GDP growth of $8-12 \%$ per year and throughout the period - an increase in the welfare of its population (Pavlovskyi, 2001: 18). In Ukraine, the economic reforms of the 90 s of the twentieth century turned not only into a prolonged economic crisis, but also a systemic crisis of society.

Back in 2009, the Director of the Institute of World Economy and International Relations of the National

ISSN 1728-9343 (Print)

ISSN 2411-3093 (Online)
Academy of Sciences of Ukraine, academician Y. Pakhomov, gave a thorough assessment of the state of Ukrainian society and its economy. "The fundamental source of crisis shocks in our country is, of course, not only the economy but also the long-term degradation of society as a whole, which has intensified in recent years, especially due to pervasive corruption, which has become the main regulator of economic processes. As a result, there was a decline in morality and the attenuation of the energy of creation, as well as the destruction of the social sphere and the undermining of the spiritual foundations of society. ... Evidence of the absolute regress of the country is the unique fact that Ukraine, unlike other post-Soviet states - Russia, Belarus, Kazakhstan, Azerbaijan, etc. for 18 years of its existence has not reached (minus 20\%) its own economic potential in 1991" (Pakhomov Yu. \& Pakhomov S., 2009: 3-4).

Neoliberal market reforms have led to radical changes in Ukraine's ownership structure. If in 1990, according to researchers, the share of state property was about $95 \%$ in the economy of Ukraine, in 2015 it decreased to a minimum, and private property, by contrast, reached $93 \%$. These structural changes meant the transformation of the state and a radical change in its social essence: the state in Ukraine increasingly acquired the characteristics of a liberal state, which appears in the role of "night watchman" of private property.

Market reforms in Ukraine were accompanied by the deindustrialization of its economy. Whole branches of industrial production were liquidated, in particular, such as the electronic and radio engineering industry, instrument making, shipbuilding, and agricultural engineering. The production of aviation and space equipment has already been brought to a deplorable state.

One of the consequences of the economy and production potential degradation was the degradation of the labour force in Ukraine. In the period from 1990 to 2015 , the number of employees decreased: in industry from 7.8 million to 2.2 million, i.e. 3.5 times; in construction - from 2.4 million to 0.2 million, 12 times; in agriculture - from 4.4 million to 0.5 million, 8.8 times; in transport - from 1.8 million people to 0.7 million, 2.5 times; in education, culture, science and art -3 million to 1.7 million, 1.7 times. The total number of employees employed in these sectors of the economy decreased from 19.4 million to 5.3 million, i.e. 3.6 times (Skvorets, 2019: 196). This is evidence that about 14 million people have been deprived of their usual jobs and sources of income. They were excluded from the spheres of society, were forced to seek new means of subsistence, to fight for survival, that is, survived the process of marginalization.

In the post-Soviet period, Ukrainian society is experiencing a deep demographic crisis. According to state statistics, in its history, Ukraine has reached the largest population on 01.01.1993, when it amounted to 52.244 million people. On 01.01.2018, the total population of Ukraine amounted to 42.234 million people. Thus, during 25 years, the population of Ukraine decreased by 10 million people, or 19\%. From 1 to 26 December 2019, Ukraine conducted a pilot electronic census, according to 
which, in Ukraine (excluding the annexed Crimea and the occupied territories of Donbass) live 37 million 289 thousand people, i.e. its population has decreased over the past 27 years by 15 million people.

Thus, market reforms have led to processes of privatization, deindustrialization, mass marginalization of the population, transition to a liberal state, depopulation of the population, i.e. those processes that determine the nature of the transformation of Ukrainian society. These processes have led to profound, sometimes radical, sociocultural changes in the lives of Ukrainian citizens.

Consider the relationship between social development and socio-cultural change in post-Soviet Ukrainian society. In understanding the transition from the Soviet model of society to the post-Soviet model, it is advisable to rely on the concepts of "social development" and "social policy".

Social development is considered by scientists as a set of relevant concepts and real practices, legislation and policies of the modern state to strengthen and improve the social welfare of the population. In addition to fulfilling its historically determined functions related to ensuring order, security, and favorable external conditions in the country, the modern state actively promotes the social welfare of the entire population by implementing a policy of centralized planning or using the Keynesian model of economic development and management. Social development supports production and consumption, promotes fuller and more efficient use of labor, development of legislation in the economic and social spheres, approval of programs to ensure education for all citizens, use of health care, housing, maintaining a normal and sufficient income in crisis situations. In developed countries, the system of social welfare has been established through a successful course of social development, to some extent neutralizing ideological differences between supporters of left and right parties and movements. Such a course makes it possible to solve many political problems of consolidation of society, easing social tensions (Rozvytok sotsialnyi, 2005: 362).

State social policy is the purposeful, systematic activities of the state to reconcile the interests of different social groups in the field of production, exchange, distribution and consumption of products, as well as the interests of the individual with the collective goals of society. This concept is based on the concept of social reproduction, the creative potential of which allows not only to analyze the set of basic social processes in society, but also to model the development of these processes and social change. The role of the state as the main subject of social policy is due to the essence of the state as an organization of political power, characterized by the supremacy of power in the territory, carries out legal regulation of relations in this territory, disposes of its resources on behalf of the people, has the exclusive right to collect taxes offenders, is responsible for the living conditions of citizens. It is the result of social development and social policy of any state is the state of development of its social sphere.
Scientists have revealed the importance of the social sphere in social reproduction, which is the basis of the evolution of social systems. "The main function of the social sphere is the function of social reproduction of various segments and groups of the population as subjects of the historical process, as well as their comprehensive livelihood. This function is one of the most important for the existence of society. It shows the need to realize the general need of the whole society to maintain their lives and prospects for the integrity of historical development. ... Reproduction of social subjects is a process of evolution of the whole system of social relations. It covers all manifestations of the life of social communities and is expressed in the continuous functioning of the social structure, social institutions, social norms and values within a specific historical formation. Being embodied in the form of cyclical reproduction of generations of people, it embodies the trends of change in the social system, which are inherent in a particular stage of social development" (Sotsialnaya politika $v$ postsotsialisticheskom obshchestve, 2001: 66).

In the 90s of the twentieth century as a result of market reforms, the state of Ukraine's social sphere found itself in a state of deep decline. This trend of social change was due to the socio-economic crisis in Ukraine, which led to a reduction in industrial production by 2.5 times and a rapid reduction in resources needed to maintain and develop the social sphere. "Consolidated budget expenditures from 1990 to 1998 decreased from 78.2 billion US dollars up to 12.4 billion US dollars, i.e. 6.3 times, including education - from 12 billion US dollars up to 1.8 billion dollars (6.7 times); for health care - from 7.9 billion dollars up to 1.5 billion dollars (5.3 times); for culture - from 1.3 dollars up to 0.1 billion dollars (13 times)" (Pavlovskyi, 2001: 16-17). From 1990 to 2001, the number of employees employed in education, science, culture and art of Ukraine decreased from 3.0 million to 2.1 million (Zbitniev, Senchenko, 2003: 36). These indicators show that the trend of social degradation of the entire post-Soviet Ukrainian society was formed to change the trend of social development.

The result of the state's social policy is a change in the social structure. In Ukraine from 1988 to 2001, the number of upper strata decreased from $19.3 \%$ to $2 \%$, middle - from $75 \%$ to $9.8 \%$, and lower - increased from $5.7 \%$ to $88 \%$ (Dubrovskyi, Andrushchenko, 2002: 25). Thus, as a result of reforms in Ukraine, the social structure, which was based on the middle classes, was replaced by a social structure in which the vast majority of the population is poor.

In 2010, V. Chernyak described the distribution of national wealth in Ukraine. He notes: "The result of inadequate, inefficient and criminal economic "reform" in Ukraine has been an unacceptably high level of concentration of national wealth owned by a small number of people, income differentiation against the background of cynical excessive luxury of the financial and political elite, poverty and impoverishment. In terms of poverty, Ukraine is among the three poorest countries in Europe, including, in addition to us, Moldova and Albania. The structure of 
distribution of national wealth in Ukrainian society can be represented as follows: $5 \%$ of the richest and rich people own $65 \%$ of wealth, $60 \%$ of the poorest and poor people $-5 \%$, the middle class (35\% of the population) owns $30 \%$ of wealth" (Cherniak, 2010: 17). Scientists have found that changes in the social status (and even more so changes in social status) of a person or social group, cause serious changes in its culture.

Social policy in recent years, as in the 90 s of the twentieth century has driven the vast majority of Ukraine's population into a struggle for survival. According to M. Shulga, extremely low living resources of the population determine a specific way of life, which is called survival. In the conditions of vital resources shortage, the person directs, concentrates the vital potential available to it on satisfaction of direct, basic needs - food, clothes, the maintenance of habitation and refuses others. All human life is centered around reproducing oneself physically and helping one's loved ones to do so in order to meet the simplest, most essential social needs. That is, it cannot satisfy other needs (cultural, leisure, creative, cognitive, the need for full maintenance and reproduction of health). Survival is a type of behavior when any promising behavioral strategies are postponed, and everything focuses on urgent, immediate tasks (Shulha, 2018: 96).

As can be seen from Figure 1, there is a clear dependence of the assessment of the state of the country by respondents based on their financial situation. The poorer a person is, the more negatively he / she perceives the state of affairs in the country. In addition, we can see that with the growth of material well-being increases uncertainty or unwillingness to answer this question.

Thus, in post-Soviet Ukrainian society there were important changes in the social sphere, the social structure of the population, the distribution of national wealth, which changed the direction of its movement from the dominance of social development to the predominance of social degradation. There was a change in the social matrix of reproduction of Ukrainian society: there was a transition from the dominance of the culture of the middle classes to the spread of the culture of the poor, the main feature of which is the struggle for survival.

\section{In general, do you think that things in Ukraine are going in the right or wrong direction?}

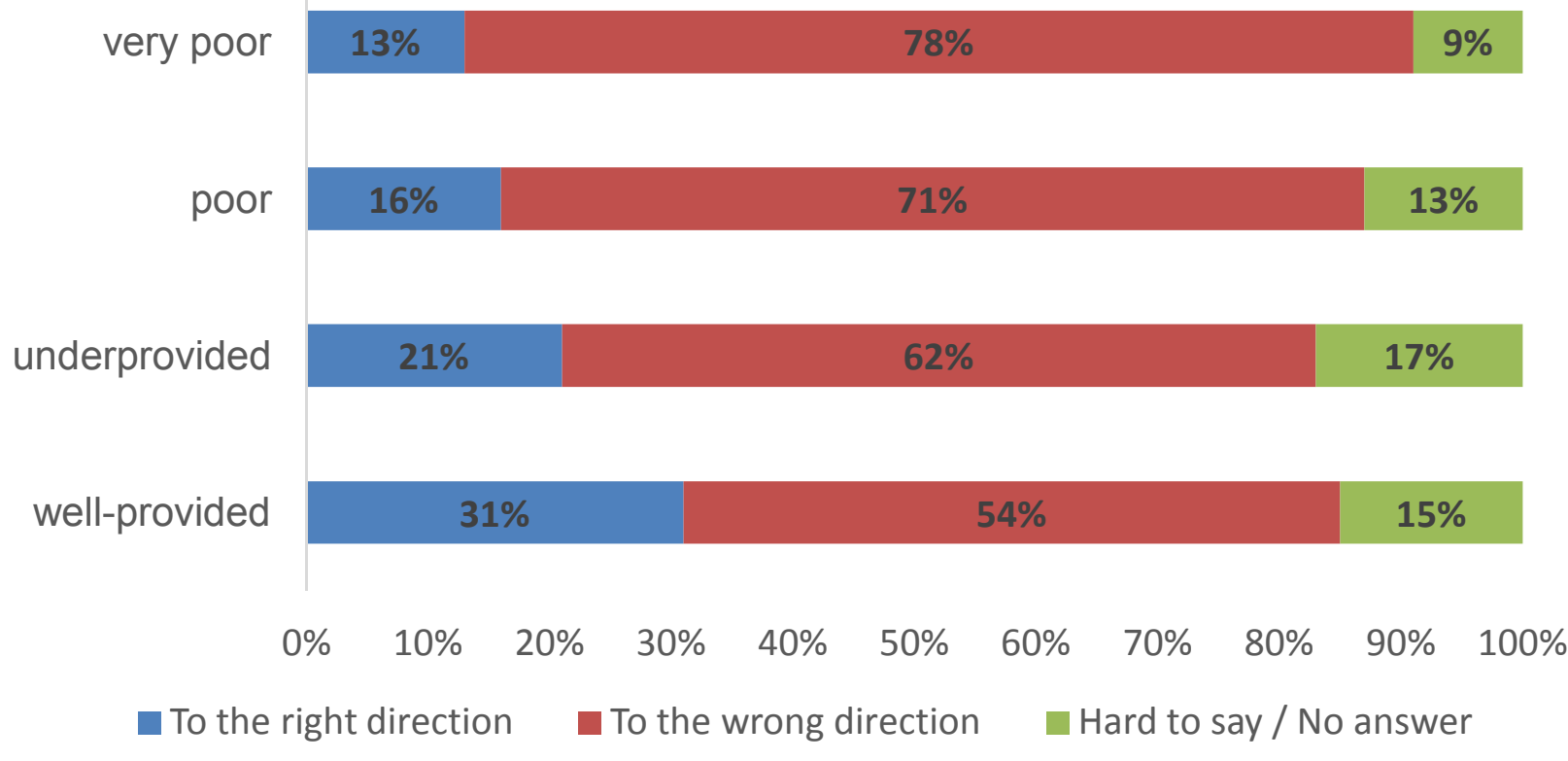

Figure 1. The results of a sociological survey by the Rating Group on citizens' assessment
of whether things in Ukraine are going in the right or wrong direction (Suspilno-politychni pohliady..., 2021: 7).

How has socio-cultural transformation changed the nature of society and the model of social governance in Ukraine?

The change in social relations, social actors and their culture in post-Soviet Ukraine means a socio-cultural transformation that has changed the nature of society and the model of social governance.

V. Heiets identified a key trend of change, which determined the content and nature of the transformation of society from the Soviet to the post-Soviet type. Although it was declared that the country set itself the task of becoming a country with a civilized market economy and achieving a result that would become a fundamental model of life, in fact, the previous model of state absolutism in Ukraine, as in other countries, moved towards market absolutism. There was a social atmosphere where the "new ideology" became "total freedom", which allows to go the way of enrichment without any restrictions, and 
pseudo-market relations were dominant in many areas, especially in the interaction of state and business (Geyets, 2009: 342). The absolutism of the state means that the state power manages all state and collective farm-cooperative property, and therefore occupies a monopoly position in the political, economic, social and spiritual spheres of society. If the market is a sphere of commodity-money circulation, then the absolutism of the market means the transformation of everything that is possible into a commodity. Thus, in the public consciousness there have been such changes that allow to turn into a commodity not only products of production, services, natural resources, land, labor, but also man himself, human life and health, power, government positions. Not only the body but also the soul of a person can be turned into a commodity.

The trend towards market absolutism underlies the socio-cultural transformation of post-Soviet Ukrainian society. It is this trend that has led to a change in the dominant socio-cultural type of person in society. This important social fact remained virtually unnoticed, and therefore unexplored, by scientists, but it was discovered by cultural and artistic figures. It is in the works of cinema that the change of the cultural-historical type of teacher is reflected: the image of the Soviet teacher and the post-Soviet one can be clearly distinguished. A number of Soviet films ("Spring on Zarechnaya street", "The first teacher", "Let's live to see Monday", "The big break" and others) created the image of a Soviet teacher - a man who fulfills an important mission to lead his students into the future, to form a personality of the student. Most educators focused on the best features of these images and were real teachers, educators and mentors of their students, and schools really functioned as a specific social environment in which there is a complex process of social interaction and spiritual growth of teachers and their students. Actor $S$. Svetlakov in the satirical and humorous program "Nasha Rasha" created the image of teacher Snizhana Denisovna, who is enriched by trusting students and their wealthy parents, resorting to deception, fraud and blackmail. As a teacher who grew up in the traditions of the Soviet school and worked at the school for a long time, I was initially offended by the image of Snizhana Denisovna, who degrades not only the dignity of a teacher, but also this difficult profession. Later I realized that the image of Snizhana Denisovna has another side: it reflects profound changes in the socio-cultural sphere of post-Soviet society. The historical and cultural type of the Soviet teacher, who saw his vocation in creating the student's personality, was replaced by a qualitatively different historical and cultural type of post-Soviet teacher who did not care about the development of the student's personality, but sought to enrich himself at the expense of students and their parents. My assumption about the transition to the dominance of commercialized teachers in the schools of modern Ukraine was confirmed in communication with part-time students who are parents of students.
The change in the historical and cultural type of personality concerns not only education, but also all other branches and spheres of life in post-Soviet Ukraine. This change concerns public administration, local selfgovernment, police, court, prosecutor's office, science, health care, culture. This does not mean that there are no more professionals in these industries, they still exist and work, but very often they have been pushed from the leading positions by outspoken amateurs, or those who pretend to be professionals. In the last 7-8 years, the practice of appointing non-professionals as heads of institutions, enterprises, state-owned companies (see the composition of supervisory boards) and even ministries has become widespread in Ukraine. There are many examples. A man without legal education, but the godfather of the President of Ukraine, Y. Lutsenko, was appointed to the position of the Prosecutor General of Ukraine, and in order to make this possible, amendments were made to the Law of Ukraine "On the public prosecutor's office of Ukraine". Here is another example that clearly shows how the replacement of professionals by people far from this profession leads to tragedy.

On September 25, 2020, an AN-26 plane crashed near Chuhuiv, killing 20 cadets and 6 crew members. Three state commissions investigated the causes of the accident and killed people, which established the fact of violation of flight regulations, but did not fully understand the causes of the accident. The commissions did not pay attention to the fact that the head of the University of the Air Force of Ukraine named after I. Kozhedub is not a military pilot, but an anti-aircraft gunner. This is a respectable man, a hero who distinguished himself in the battles of the anti-terrorist operation. But the question of the causes of the tragedy: is a person who is not a military pilot able to provide reliable and safe training for military pilots? Only a military pilot who has the appropriate professional path and experience can manage the real training of military pilots, which ensures not only the formation of their practical skills, but also safety. It must be a pilot who has personally flown ten or two thousand hours, mastered 5-7 types of aircraft, has experience in training pilots, that is, has the necessary qualities to successfully and safely train military pilots. It is this approach, which puts the professionalism of the individual in the first place, that was the main criterion in the personnel policy of the USSR regarding the appointment of heads of all educational institutions, especially the military. In the late 90's in the newspaper of the Verkhovna Rada of Ukraine "Voice of Ukraine" there was an interesting report: after the appointment to the post of head of the Kirovograd Academy of Civil Aviation, a person who is not a pilot, a year later graduates were awarded diplomas, but without hours of flight.

Let's turn once again to the results of opinion polls. As can be seen from Figure 2, most innovations in Ukraine are perceived by respondents as pessimistic, namely: "unsuccessful" ratings (pink and red) predominate The two exceptions are the decentralization reform, which has increased the financial independence of the regions from the center, and the related infrastructure reform. The 
decommunization reform should be singled out - not for the significant number of assessments "unsuccessful", but for the number of uncertain answers. If you look at the assessment of social reforms, you can see the predominance of "unsuccessful" assessments, which generally range from $57 \%$ (police reform) to $71 \%$ (anti-corruption reform).

The ruling class of post-Soviet Ukraine, which led society through social degradation, also moved through degradation that escalated into degeneration, and the degeneration of the ruling class manifested itself in the loss of the ability to preserve the integrity of society and the state. Evidence of the degeneration of the ruling class is the demonstration by its representatives of their social parasitism.

As a result of the influence of these processes, culture did not fulfill its main role as an integrator of society in post-Soviet Ukraine. In addition, post-Soviet Ukrainian society has experienced three social traumas ("shock therapy" of market reforms, the military conflict in eastern Ukraine, and the coronavirus pandemic), but they have only complicated the situation in order to preserve the integrity of society.

\section{In your opinion, to what extent were the subsequent reforms successful or unsuccessful after 2014?}

\section{- Very successful \\ Both successful and unsuccessful \\ - Absolutely unsuccessful \\ Difficult to answer / No answer}

Judicial reform

Anti-corruption reform

Health care reform

Educational reform

Law enforcement reform as a patrol police reform

Decentralization and local selfgovernment, including community associations

Decommunization

Infrastructure (roads, bridges)
Rather successful

Rather unsuccessful

I do not know anything about the course of this reform
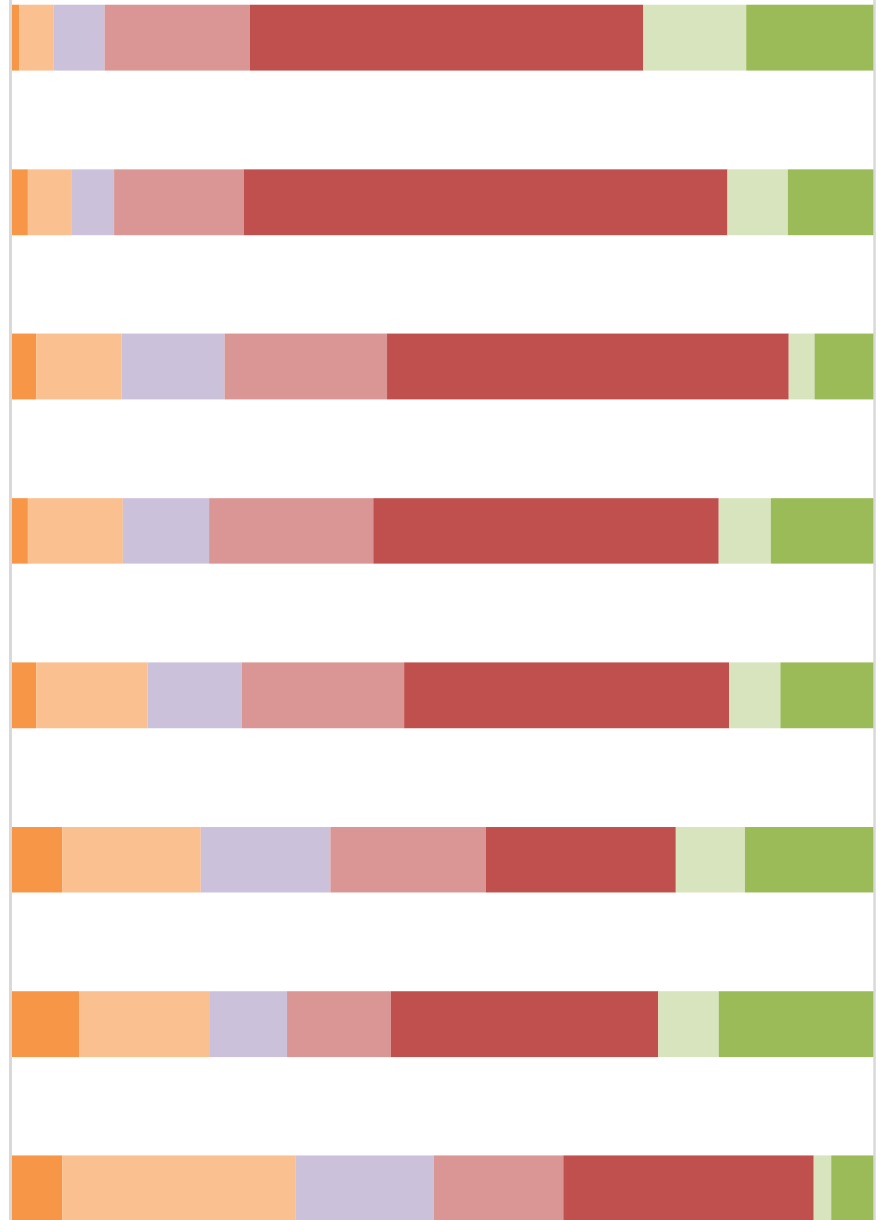

Figure 2. The results of a sociological survey by the Rating Group: citizens' assessment of the extent to which subsequent reforms were successful or unsuccessful after 2014

(Suspilno-politychni pohliady..., 2021: 92). 


\section{Conclusions}

Thus, the essence of the socio-cultural transformation of post-Soviet Ukrainian society is the transition from the absolutism of the state to the absolutism of the market, which means the transformation of everything possible into a commodity, and the dominance of commoditymoney relations in all spheres of public life. This transition was accompanied by a change in the historical and cultural type of human personality, commercialization, deprofessionalization, as well as the primitivization of public administration in various industries. All these processes have been imprinted by the social traumas experienced by society, which causes a contradictory state of culture, which complicates the reproduction of society as a whole. The Soviet way of life has been dismantled, and the failure of the social matrix indicates that a new way of life in post-Soviet Ukraine has not yet been formed, and therefore socio-cultural transformation must be aimed at its formation.

\section{REFERENCES}

Cherniak, V.K. (2010). Postkryzova ekonomika: kapitalizm z «liudskym oblychchiam». Ekonomichnyi chasopys - XXI. 1-2. http://www.nbuv.gov.ua/portal/soc.../5-Cherniak.pdf (In Ukrainian).

Dubrovskyi, M. \& Andrushchenko, A. (2002). Systema i transformatsii: prohramne zabezpechennia rozvytku suchasnoho profspilkovoho rukhu $v$ Ukraini. Profspilky Ukrainy. 5: 25-28 (In Ukrainian).

Geyets, Valery (2009). Razvitiye i krizisy v Ukraine protivorechiya transformatsii Metodolohiia, teoriia ta praktyka sotsiolohichnoho analizu suchasnoho suspilstva. Zbirnyk naukovykh prats, 15. (In Ukrainian).

Giddens, E. (1999). Sotsiologiya [Trans. from English]. Moscow: Editorial URSS. P. 32-34 (In Russian).

Pakhomov, Yu. \& Pakhomov, S. (2009). Sytuatsyia v Ukraine: predkryzys, kryzys, postkryzys. Ekonomichnyi chasopys - XXI. 7-8: 3-6. http://dspace.nbuv.gov.ua/handle/123456789/45327

Pavlovskyi, M. (2001). Stiikist ekonomichnoi systemy. Vid rytoryky do dii. Viche. 3 (108): 18-34 (In Ukrainian).

Pavlovskyi, M.A. (2001). Stratehiia rozvytku suspilstva: Ukraina i svit (ekonomika, politolohiia, sotsiolohiia). Kyiv: Tekhnika, 312 p. (In Ukrainian)

Rozvytok sotsialnyi (2005). M.F. Holovatyi (ed.), M.B. Panasiuk (ed.). Sotsialna polityka $i$ sotsialna robota: Terminol.-poniatiin. slov. Kyiv: MAUP, P. 362 (In Ukrainian).

Shulha, M. (2018). Zbii sotsialnoi matrytsi. Kyiv: Instytut sotsiolohii NAN Ukrainy, 284 p. (In Ukrainian)

Shulha, M.O. (2011). Dreif na uzbichchia. Dvadtsiat rokiv suspilnykh zmin $\vee$ Ukraini. Kyiv: Biznespolihraf Ltd, 448 p. (In Ukrainian)

Skvorets, V.O. (2013). Zhyttieustrii narodu: sotsialnofilosofskyi analiz. Doctor Thesis. Dnipropetrovsk National University. (In Ukrainian)

Skvorets, V.O. (2019). Transformatsiia sotsioistorychnoho orhanizmu Ukrainy: analityka sotsialnykh protsesiv. Zaporizhzhia: Zaporizhzhia National University. 520 p. (In Ukrainian)

Sotsialnaya politika $v$ postsotsialisticheskom obshchestve: Zadachi. Protivorechiya. Mekhanizmy (2001). Moscow: Nauka. (In Russian)

Stiglitz, J. (2002). Globalization and Its Discontents. New-York - London: W.W. Norton \& Co.

Suspilno-politychni pohliady v Ukraini (2021, March 13-21). Rating Group Ukraine. http://ratinggroup.ua/ru/research/ukraine/opros_iri_obschestvennopoliticheskie nastroeniya $\bar{v}$ ukraine.html

Zbitniev, Yu.I., Senchenko, M.I. (2003). Bila knyha Ukrainy abo Vashynhtonskyi konsensus $v$ dii. Naslidky ekonomichnykh reform 1991-2001 rokiv. Kyiv: Vyd. dim «Kniahynia Olha», 2003. (In Ukrainian).

\author{
Володимир Скворець, \\ Запорізький начіональний університет (Запоріжжя, Україна) \\ e-mail: skvorets.v.o@gmail.com, ORCID 0000-0001-7558-0773
}

Ігор Кудінов,

Запорізький начіональний університет (Запоріжжя, Украйна)

e-mail: info@igorkudinov.pro,ORCID0000-0001-7785-1637

\title{
СОЦІОКУЛЬТУРНА ТРАНСФОРМАЦІЯ В ПОСТРАДЯНСЬКІЙ УКРАЇНІ
}

Актуальність проблеми дослідження полягає в тому, що осмислення соціокультурної трансформації дозволяє виділити соціальні процеси, які впливають на функціонування пострадянського українського суспільства. Предметом дослідження є соціальні процеси, що визначають зміст і характер соціокультурної трансформації пострадянського українського суспільства. Метою статті є осмислення впливу соціокультурних змін на функціонування пострадянського українського суспільства. Методологія дослідження соціокультурної трансформації ґрунтується на використанні системного, логічного, історичного, діалектичного і соціокультурного підходів та методів. У результаті дослідження виявлено, що в пострадянській Україні загальний контекст соціокультурних змін зумовлений реалізацією ринкових реформ, що спричинили процеси приватизації, деіндустріалізації, масової маргіналізації населення, переходу до ліберальної держави та депопуляції населення. Ці процеси зумовили соціокультурні зміни в житті громадян України. Відбулися важливі зміни в соціальній сфері, соціальній структурі населення, розподілі національного багатства, що змінили напрямок його руху із домінування соціального розвитку на переважання соціальної деградації. Відбулася зміна соціальної матриці відтворення суспільства: від домінування культури середніх верств населення відбувся перехід до поширення культури бідних, основною 
ознакою якої є боротьба людини за виживання. Зміст соціокультурної трансформації пострадянського українського суспільства полягає в переході від абсолютизму держави до абсолютизму ринку, що означає перетворення всього, що можливо, на товар, і домінування товарно-грошових відносин у всіх сферах суспільного життя. Цей перехід супроводжувався зміною історико-культурного типу особистості людини, комерціалізацією, депрофесіоналізацією, а також примітивізацією державного управління. Зміни стану культури ускладнили відтворення суспільства як цілісності. Радянський життєустрій був демонтований, а збій соціальної матриці засвідчує про те, що новий життєустрій в пострадянській Україні сформувати ще не вдалося, а тому соціокультурну трансформацію необхідно спрямувати саме на його формування. Практична цінність результатів полягає в обґрунтуванні змісту соціокультурної трансформації в пострадянській Україні та її впливу на функціонування суспільства.

Ключові слова: життєустрій народу, соціальна матриця, суспільне відтворення, соціальна трансформація, соціальний розвиток, соціальна деградація, соціокультурні зміни.

(C) Volodymyr Skvorets, Igor Kudinov

Надійшла до редакції: 03.05.2021

Прийнята до друку: 21.06.2021 